\title{
Behavior of Female Entrepreneurs in Tempe Small Micro Enterprises in Tasikmalaya Regency, West Java as Proof of Gender Equality Against AEC
}

\author{
Ivonne Ayesha ${ }^{1}$, Finny Redjeki ${ }^{2}$, Acai Sudirman ${ }^{3}$, Avid Leonardo \\ $\mathrm{Sari}^{4}$, Diena Fanny Aslam ${ }^{5}$
}

\author{
${ }^{1}$ Universitas Muhammadiyah Bandung \\ ${ }^{2}$ Universitas Sangga Buana Bandung, Indonesia \\ ${ }^{3}$ Sekolah Tinggi Ilmu Ekonomi Sultan Agung \\ ${ }^{4}$ UIN Sunan Gunung Djati, Bandung \\ ${ }^{5}$ GoAcademica Result and Publishing \\ drivonneayesha@gmail.com
}

\begin{abstract}
MSEs are the primary modes of industry in Indonesia, up to $90 \%$ of them. However, there is a tendency for entrepreneurs to be associated with big companies. The purposive sampling technique was carried out by selecting 121 respondents. Structural Equation Modeling (SEM) is often used to predict entrepreneurial activity. The findings of this analysis suggest that there are entrepreneurial traits in MSEs. There are more notable entrepreneurial characteristics in large-scale production, and these characteristics can be the initial capital of society, especially women, to face AEC. This positive characteristic needs great and serious support from the Tasikmalaya district government. Entrepreneurial characteristics have the most influence on entrepreneurial behavior. Besides, entrepreneurship also has a positive and important influence on company results. Thus, this research shows that entrepreneurship activity is still taking place in small industries, not just in big businesses.
\end{abstract}

\section{Keywords: Small Micro Enterprises (SMEs), Structural Equation Models, AEC, Tempe Industry}

\section{INTRODUCTION}

Entrepreneurship is believed to be the driving force of economic growth, and entrepreneurship is also considered an innovator in economic development (Wennekers \& Thurik, 1999; Carree \& Thurik, 2010; Acs \& Armington, 2006). The high percentage of entrepreneurs in a country means that the country's economy will grow well. The number of Indonesian entrepreneurs in 2019 reached 1.90 percent of Indonesia's total population (Febianto, 2012; Athoillah, 2018). This number is also small relative to other Asian nations, such as China and Japan, where entrepreneurs account for more than $10 \%$ of the total population (Abdul, 2011). In the Southeast Asian region, Indonesia is still below Malaysia, which has reached the figure $(5 \%)$ or Singapore $(7 \%)$. MSMEs mostly dominate business actors in Indonesia. The number of small and medium-sized companies in Indonesia amounts to 56 million business units. However, the owner of this business is not counted as an entrepreneur following the Ministry of Cooperatives' evaluation (Triyono, 2019). Referring to the definition of entrepreneurship, an individual who can create something by working alone can face risks by taking advantage of existing opportunities. These MSMEs have an essential role for the country, namely the absorption of labor and GDP contribution. The role and existence of MSMEs in employment and their contribution to the National Gross Domestic Product (GDP) are no longer in doubt (Indarti, 2019).

One of the developing types of Micro and Small Enterprises (MSEs) is making tempeh. In Indonesia, tempeh is known as typical Indonesian food. These business actors are also scattered in West Java, one of which is in the Tasikmalaya Regency. These business actors are mostly dominated by migrants who come from Pekalongan, Central Java. This business has unique characteristics; the supply of raw materials for making tempe is $100 \%$ obtained from imported soybeans. Thus, any change in soybean prices will directly affect business 
development and artisans' behavior in dealing with this situation (Anggadwita, 2016). Most of these businesses are hereditary, traditional, and have a household scale. However, even though this business is constrained by the price of raw materials and capital, business actors continue to operate for many years even though the business development is not significant (Rinaldo, 2013).

Therefore, the behavior mentioned earlier becomes the basis behind this research on entrepreneurial behavior at MSEs. This research focuses on entrepreneurial action at MSEs due to the unique characteristics and characteristics of MSEs that large businesses do not have. The difficulty of raw materials, the increased prices of raw materials, lack of an acceptable place to open a shop, and limited capital do not prevent this business from running (Pakkanna, 2015). Another characteristic of MSEs is that they are weak in planning, soft in working with other individuals, suppliers, investors, and other entrepreneurs. Micro entrepreneurs have not been able to position themselves as quality and subsistence entrepreneurs (Alami, 2017). However, MSEs can survive running a business for years even though significant business developments do not follow them. Yet, not all of these business actors are categorized as entrepreneurs (Vyas, 2009). As women who do traditional culinary businesses, they still have many shortcomings in processing culinary dishes and mentally as entrepreneurs. So far, female culinary business traders only run naturally and rely on their instincts, with minimal capital. The touch of the Tasikmalaya Regency government has been less than optimal (Martiana, 2018). Therefore, all women traders do not care about AEC because of the helplessness of their thoughts and efforts (Suwana, 2017). Tasikmalaya regional officials have often repeatedly said that the winners in all competitions have reliable abilities and skills. The fact is that the government has not taken real action to make it happen (Faizah, 2019). As a result, some women traders are desperate, leaving traditional culinary businesses, and some even rent out their stalls.

\section{METHOD}

The study was carried out in Tasikmalaya District, West Java, from December 2018 to February 2019. In Tasikmalaya, the third largest number of UCMs in the west of Java with 22,337 units were chosen deliberately for their position. Due to its special properties, the option of the tempe industry to be investigated. Main and secondary data types used in this study. Preliminary information was obtained by a direct questionnaire interview. Secondary data were collected from different relevant institutions, such as the Ministry of Cooperatives and SMEs, the Central Statistical Agency, the Government of the West Java Province, and the Tasikmalaya Kopti. A survey of 121 tempe craftsmen was achieved by a purposeful sampling method. This estimation is dependent on SEM analytical methods, which need a broad sample size. This is because the findings of the study will approach variables that impact entrepreneurial activity in tempering artisans in the Tasikmalaya district and explain them.

\section{RESULT AND DISCUSSION Characteristics of Micro and Small Business Entrepreneurs in Women Tempe Craftsmen}

Analysis of entrepreneurial characteristics is obtained from calculating the results of interviews with the help of Likert assessments. This analysis is based on six variables (experience, innovation, risktaking, perseverance, leadership, and motivation) because an entrepreneur has innovative characteristics or traits, has a leadership spirit, is willing to take risks, explains, and is also diligent and experienced. The values of the six variables used as a measure for grouping respondents have high, low, and medium entrepreneurial characteristics. To see the entrepreneurial features in the tempe business, grouping into three business scales is carried out based on the amount of production. Production quantities less than $50 \mathrm{Kg}$ are categorized as small scale, 51-100 $\mathrm{Kg}$ as medium scale, and more than $100 \mathrm{Kg}$. Basis of the findings of the survey, respondents with high market characteristics $(71 \%)$ are mostly distributed across broad business sizes.

Based on this distribution, it can explain how the entrepreneurial character of women tempe craftsmen. 121 people took the number of respondents, the number of respondents on a small scale business as many as 63 people (52\%), a medium-scale as many as 51 people $(42 \%)$, and a large scale as many as 7 people $(6 \%)$. Based on this number, most of the women tempe producers in Tasikmalaya have low entrepreneurial characteristics.

The importance of innovation emphasizes that an entrepreneur's success must have a creative and innovative character (Cahyono, 2018). Creativity is generating new ideas or ideas without realizing these ideas or being a prerequisite for innovation, while innovation is the application of creative ideas (Movono, 2017). A new concept has value if the concept can be applied to a product. 
Meanwhile, tempe craftsmen who have low entrepreneurial characteristics do not dare to take risks. It is proven by artisans who produce tempe in the same amount from the beginning of opening a business until now with a minimal amount, which is less than $50 \mathrm{~kg}$. These craftsmen are also satisfied with their income, so there is no motivation to increase their business volume, so they are only oriented towards meeting family needs. Traditional micro and small enterprises do not have a growth and innovation orientation. Several factors can hinder business success, including (1) Lack of managerial skills; (2) lack of experience; (3) lack of capital; and (4) Inability to respond to change and adapt to change. Based on the research results, the lack of managerial ability of tempe artisans can be seen from the absence of bookkeeping records and the absence of separation of family and company finances.

\section{Analysis of the Entrepreneurial Behavior of Micro and Small Businesses in Tempe Craftsmen Using the Structural-Equation Models (SEM) Approach}

The t-value below 1.96 means that the loading factor is not significant. While the loading factor value below 0.3 can be eliminated because the standard loading factor's limit value is $<0.50$. However, a tolerable loading factor limit is $<0.50$, but still, $\geq 0.30$ can be maintained. A flawed model needs to be respecified to produce the best model with criteria that meet the goodness of fit. is a structural model of entrepreneurial behavior in tempe artisans after respecification can be seen in Figures 3 and 4.

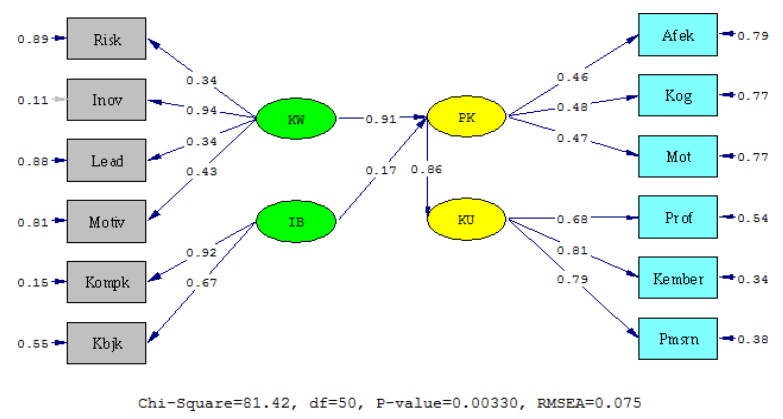

Figure 1. Standardized Coefficient Structural Model of Entrepreneurial Behavior of Tempe SMEs

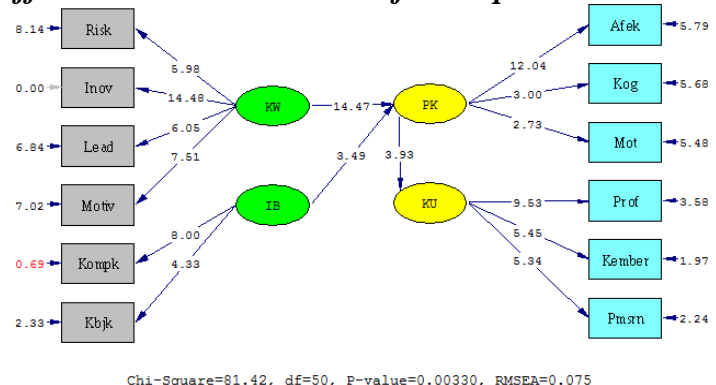

Figure 2. T-value of Entrepreneurial Behavior Structural Model of Tempe MSEs

After obtaining the best model of the specification results, the overall model fit is tested. The fittest of the structural model as a whole can be seen in the Goodness of Fit (GOF) measure. Following are the results of the most qualified of the whole model after respecification compared to the fit test of the whole model before recessification (initial model) can be seen in Table 2 .

\section{The Influence of Entrepreneurial Characteristics on the Entrepreneurial Behavior of Micro and Small Enterprises in Tempe Craftsmen}

Based on a model that has been respecified (good fit) in the previous explanation. It is clear that entrepreneurial characteristics directly influence entrepreneurial behavior. The influence of entrepreneurial traits explained by the latent variable of entrepreneurial characteristics $(\mathrm{KW})$ on 
entrepreneurial behavior $(\mathrm{PK})$ in tempe artisans is very dominant, which is $(\gamma=0.91)$ (Figure 3$)$. Based on the value of the loading factor, it can be seen that entrepreneurial characteristics influence behavior very strongly because of the immense value of the loading factor. The variable that most reflects the entrepreneurial character of tempe artisans is innovative $(\lambda=0.94)$.

Table 2. Result of Goodness of Fit Test)

\begin{tabular}{|c|c|c|c|c|c|}
\hline \multirow{2}{*}{ Goodness of Fit } & \multicolumn{3}{|c|}{ Early Models } & \multicolumn{2}{|c|}{ After Respecification } \\
\hline & Cutt off value & Result & Information & Result & Information \\
\hline Significance Probability(P-value) & $\leq 0.05$ & 0.000 & Good Fit & 0.0033 & Good Fit \\
\hline Chi square & As small as possible & 326.41 & - & 81.42 & - \\
\hline Root AECn Square (RMR) & $\leq 0.05$ atau $\leq 0.1$ & 0.12 & Poor Fit & 0.089 & Good Fit \\
\hline $\begin{array}{l}\text { RMSEA(Root AECn square Error } \\
\text { of Approximation) }\end{array}$ & $\leq 0.08$ & 0.13 & Poor Fit & 0.075 & Good Fit \\
\hline $\begin{array}{c}\text { AGFI(Adjusted Goodness of Fit } \\
\text { Index) }\end{array}$ & $\geq 0.90$ & 0.82 & Marginal Fit & 0.92 & Good Fit \\
\hline GFI(Goodness of Fit $)$ & $\geq 0.90$ & 0.87 & Marginal Fit & 0.95 & Good Fit \\
\hline CFI (Comparative Fit Index) & $\geq 0.90$ & 1.00 & Good Fit & 0.96 & Good Fit \\
\hline Normed Fit Index (NFI) & $\geq 0.90$ & 1.00 & Good Fit & 0.89 & Marginal Fit \\
\hline
\end{tabular}

\section{The Influence of Business Climate on Entrepreneurial Behavior of Micro and Small Enterprises in Tempe Craftsmen}

The business climate's effect described by the latent variable of business climate (IB) on entrepreneurial behavior based on the Structural Equation Models is $(\gamma=0.17)$. It is significant with $t$ count value of 3.49. Business climate factors that affect entrepreneurial behavior can be reflected or characterized by the cohesiveness variable among tempe craftsmen $(\lambda=0.92)$, government policy $(\lambda=$ $0.67)$. The cohesiveness of tempe artisans makes a high contribution to the business climate. This is also proven by the results of interviews that tempe artisans do have good cohesiveness. For example, when a high soybean price increased, the compact tempe craftsmen held a demonstration to the government to reduce the soybean price.

Meanwhile, another business climate indicator that contributes is government policy (Marwah, 2019). This government policy is related to the input pricing policy. Tempe producers expect the government to make soybean prices stable. The loading factor of government policies that contribute to the business climate is $(\lambda=0.67)$. But overall, the market environment indicator has a favorable and important impact even though the loading value is small. It is possible that the influence of the business climate on entrepreneurial behavior is not too considerable (Tohani, 2019). This is indicated by the strong desire and motivation of tempe artisans to keep running the business even though the input price increases (Nurwulan, 2018).

\section{The Influence of Entrepreneurial Behavior on the Performance of Micro and Small Enterprises in Tempe Craftsmen}

$(\beta=0.86)$ is significant with $\mathrm{t}$-count value of 3.93. Entrepreneurial behavior is a latent variable whose effect cannot be seen directly but through indicators that characterize or reflect. Entrepreneurial behavior is reflected by three indicator variables, namely affective $(\lambda=0.46)$, cognitive $(\lambda=0.48)$, and motoric $(\lambda=0.47)$. The biggest contribution is cognitive (knowledge), which can reflect the entrepreneurial behavior of tempe artisans.

Based on the findings of the SEM report, it can be seen the factors that affect entrepreneurial activity and market. Therefore, increasing entrepreneurial action will improve the business performance of tempe craftsmen. This is confirmed by research by Dirlanudin (2010) and Puspitasari (2013), which show that entrepreneurial behavior has a direct effect on business success, namely increased profits, increased 
number and customer loyalty, increased sales volume, increased product quality and quantity, product diversification, expansion marketing, as well as the ability to compete. Based on this research, business performance is explained by the increase in profit $(\lambda=$ $0.68)$, competitiveness $(\lambda=0.81)$, and marketing (expansion of the marketing area and customer loyalty) with a loading factor $(\lambda)$ of 0.79 .

\section{Independence of Tempe Entrepreneurial Women Resources Facing the Era of AEC competition}

The weakness of women tempe entrepreneurs' independence in the Tasikmalaya district is inseparable from the real condition of the fate of Indonesian women. The Ministry of Women's Empowerment and Security reports that as many as $60 \%$ of small and medium-sized businesses in Indonesia are women (Fitrianggraeni, 2019). HDI (Human Development Index) shows that Indonesia's human capital are ranked 6th by other ASEAN countries, such as Malaysia, Thailand, Brunei, the Philippines and Singapore. Meanwhile, figures from the Asian Productivity Organization (APO) estimated that there were just around 4.3 per cent of the professional labor force out of every 1,000 Indonesian employees in 2019. This result is well behind the Philippines (8.3 per cent), Malaysia (32.6 per cent) and Singapore (34.7\%) (Nadim, 2017).

Based on the understanding of independence and the socialization process of autonomy, at least three sources can be identified that can stimulate the development of autonomy of Indonesian women: (1) As a consequence, they are raised in conditions of socio-economic vulnerability; (2) As a manifestation of traditions and social systems that encourage the independence of women as members of society; (3) As a consequence of his educational background and experience (Muljono, 2019).

By observing what other women are doing in their environment, they also follow the consequence of this behavior. Based on her observations, she did things that were determined by her background as a woman. Understanding her sexual role as a woman is usually added by listening to people's advice or stories about what it means to be a woman. That slowly starts developing knowledge about their sexual identity and learning about the differences between women and men, including the stereotypes that apply in their environment about what women or men should do (femininity and masculinity).

Another source that spurs women's independence is the traditions and social systems of several tribes. Javanese and Sundanese women always have an essential role in economic life. This role is closely related to the practice in these tribes regarding male family members who leave the family to seek experience and look for work. Education as a process, besides providing expertise to develop one's mind, also includes background to apply the knowledge and expertise acquired independently. Independence in education will increase the quality of human capital and natural resources that are very important to the development of a nation. Macro-human resource development is a process of improving humans' quality or capacity to achieve a national development goal. The method of improvement here includes planning, development, and management of human resources.

\section{CONCLUSION}

The findings of the present analysis can be drawn from the following conclusions: (1) the existence of market characteristics in microenterprises and small enterprises and, as the manufacturing size is broadly increased, the entrepreneurial characteristics are strengthened; This demonstrates that improved creativity, risk courage, leadership, entrepreneurship, cohesiveness and government policy can boost entrepreneurship. (3) Entrepreneurship can have an impact on market success that is optimistic and significant. The findings suggest that increasing the business activity of the temperament craftsmen would improve their business success. It is only in the microand small business field of the Temporary Artisans in Tasikmalaya, West Java and cannot be extended to micro, or small companies. The reach of this research is limited. Other. Some. Thus more research on entrepreneurial behavior in various industries is needed; and (4) the district of Tasikmalaya must be stronger in empowering traditional female entrepreneurs so that they are viable and prepared to face up to AEC and work so that entrepreneurs can have enough skills and knowledge, for example.

\section{REFERENCES}

[1] Abdul, H. A., Rozman, M. Y., \& Buang, A. (2011). The Imperative of Training for Women's Economic Empowerment-Statistical Evidence from Indonesia. World Applied Sciences Journal, 13(13 SPE), 39-45.

[2] Acs, Z. J., \& Armington, C. (2006). Entrepreneurship, Geography, and American Economic Growth. Cambridge University Press. 
[3] Alami, A. N., \& Raharjo, S. N. I. (2017). Recognizing Indonesian Fisherwomen's Fishery Resource Management Roles: The Profile, Policy, and Strategy for Economic Empowerment. Journal of the Indian Ocean Region, 13(1), 40-53.

[4] Anggadwita, G., \& Dhewanto, W. (2016). The Influence of Personal Attitude and Social Perception on Women Entrepreneurial Intentions in Micro and Small Enterprises in Indonesia. International Journal of Entrepreneurship and Small Business, 27(2-3), 131-148.

[5] Anggadwita, G., \& Dhewanto, W. (2016). The Influence of Personal Attitude and Social Perception on Women Entrepreneurial Intentions in Micro and Small Enterprises in Indonesia. International Journal of Entrepreneurship and Small Business, 27(2-3), 131-148.

[6] Athoillah, M. A. (2018). The Zakat Effect on Economic Growth, Unemployment, and Poverty in The Island of Java: Panel Data Analysis 2001-2012. Ekspansi: Jurnal Ekonomi, Keuangan, Perbankan dan Akuntansi, 10(2), 205-230.

[7] Cahyono, A. E., Kurniawan, M. U., Sukidin, S., \& Kantun, S. (2018). Community Empowerment Models of Tourism Village Based on Superior Commodities: Realizing Economic Resilience. The Journal of Distribution Science, 16(11), 29-36.

[8] Carree, M. A., \& Thurik, A. R. (2010). The Impact of Entrepreneurship on Economic Growth. In Handbook of Entrepreneurship Research (pp. 557-594). Springer, New York, NY.

[9] Faizah, S. I., \& Husaeni, U. A. (2019). Economic Empowerment for Poor Women Using Grameen Bank Model in Indonesia. KnE Social Sciences, 880-913.

[10] Febianto, I., \& Ashany, A. M. (2012). Qardhul Hasan's impact using Zakah funds on economic empowerment (Case study of Dompet Dhuafa, West Java, Indonesia). Asian Business Review, 1(1), 15-20.

[11] Fitrianggraeni, S. (2019). Building business, enriching lives: an Indonesian initiative to empower women in the fishing communities. WMU Journal of Maritime Affairs, 18(4), 595-616.

[12] Indarti, N., Rostiani, R., Megaw, T., \& Willetts, J. (2019). Women's involvement in economic opportunities in water, sanitation, and hygiene
(WASH) in Indonesia: Examining personal experiences and potential for empowerment. Development Studies Research, 6(1), 76-91.

[13] Martiana, A. (2018). Motivation And Obstacles Faced By Women Halal Fashion Entrepreneurs And Role Of The Business On Women's Economic Empowerment Yogyakarta Indonesia. Humanities \& Social Sciences Reviews, 6(2), 106-110.

[14] Marwah, S. (2019). Women of the South Coast of Java in Politics and Rural Development. Journal of International Women's Studies, 20(7), 57-71.

[15] Movono, A., \& Dahles, H. (2017). Female empowerment and tourism: A focus on businesses in a Fijian village. Asia Pacific Journal of Tourism Research, 22(6), 681-692.

[16] Muljono, P., Purwono, J., \& Cahyadi, E. R. (2019). Economic Empowerment Index of Posdaya as Participatory of Community Empowerment Program in Indonesia. Italian Sociological Review, 9(1), 65-96.

[17] Nadim, S. J., \& Nurlukman, A. D. (2017). The impact of women empowerment on poverty reduction in rural areas of Bangladesh: Focusing on the village development program. Journal of Government and Civil Society, 1(2), 135-157.

[18] Nurwulan, R., \& Mariane, I. (2018). Strengthening Abg Cooperation In Women Empowerment Through Corporate Social Responsibility (CSR). Journal of Economic Empowerment Strategy (JEES), 1(1), 46-57.

[19] Pakkannaa, M., Arsyadb, L., \& Suryantoroc, A. (2015). Economic Empowerment of Rural Women: Case Study of Microfinance Institutions (MFIs) in Tangerang, Indonesia. Sociology Study, 5(11), 865-874.

[20] Rinaldo, R. (2013). Mobilizing piety: Islam and feminism in Indonesia. Oxford University Press.

[21] Suwana, F. (2017). Empowering Indonesian women through building digital media literacy. Kasetsart Journal of Social Sciences, 38(3), 212-217.

[22] Tohani, E., Prasetyo, I., \& Suharta, R. B. (2019). Women Empowerment In Disaster Vulnerable Village Through Vocational Life Skill Education Based On Utilization Of Local Potential. Journal of Nonformal Education, 5(1), 35-46.

[23] Vyas, S., \& Watts, C. (2009). How does economic empowerment affect women's risk of 
intimate partner violence in low and middleincome countries? A systematic review of published evidence. Journal of International Development: The Journal of the Development Studies Association, 21(5), 577-602.

[24] Wennekers, S., \& Thurik, R. (1999). Linking Entrepreneurship and Economic Growth. Small Business Economics, 13(1), 27-56. 